\title{
Signatures of key petroleum system elements: outcrop examples from the Anambra Basin, Southeastern Nigeria
}

\author{
Chidozie Izuchukwu Princeton Dim ${ }^{1} \cdot$ Ayonma Wilfred Mode ${ }^{1} \cdot$ Ikenna Christopher Okwara $^{1}$
}

Received: 15 September 2017 / Accepted: 23 November 2018 / Published online: 1 December 2018

(c) The Author(s) 2018

\begin{abstract}
Although several works have proved the existence of oil and gas in the Campanian to Maastrichtian strata of the Anambra Basin, it is still considered a frontier basin due to the challenges associated with interpretation of stratigraphy and structure arising from non-availability of subsurface data. This has led to poor understanding of the petroleum system and hindered exploration activity within the basin. This research paper aims to discuss the signatures of essential petroleum system elements, based on the study of high-quality outcrop examples. Detailed field studies reveal the presence of source, reservoir and seal rocks, and traps exposed within the four lithostratigraphic units outcropping in the basin, across the southeastern part of Nigeria. The shales of Enugu Formation, offer good source rocks. The shales, coals, coaly shales and sandstones with repeated occurrence of shale-silt-sand heteroliths of the Mamu Formation provide possible source and reservoir rocks. Thick extensive sandstones with clay laminae of the Ajali Formation offer potential reservoir that are partly compartmentalized. The shales with interstratified sandstone of the Nsukka Formation provide potential cap and overburden rocks. The presence of anastomosing fracture bands, extensional joints and faults, small-scale growth faults, and rollover anticlinal structures are good evidence of structural and stratigraphic configuration that could allow for possible migration, accumulation and entrapment of hydrocarbon. These recognized signatures of the key elements of a petroleum system and oil seeps encountered in the basin are an indication of the presence of an active petroleum system.
\end{abstract}

Keywords Anambra Basin $\cdot$ Outcrop $\cdot$ Reservoir rock $\cdot$ Source and seal rocks $\cdot$ Structural trap

\section{Introduction}

Several works have been carried out within the Anambra Basin, however, these works were focused on basinal extent, tectono-stratigraphic evolution, sedimentary fill, lithostratigraphy age, lithological characteristics, sequence stratigraphic framework and depositional environments (Burke et al. 1971; Benkhelil 1982; Nwajide and Reijers 1996; Nwajide 2006, 2013; Dim et al. 2017). Only few of these works were targeted at hydrocarbon prospectivity (Ekweozor 1982; Ekweozor and Gormly 1983; Obaje et al. 1999, 2004; Nwajide 2005, 2013; Anyiam and Onuoha 2014; Anyiam et al. 2015; Dim et al. 2018a). Hence, more of these research is needed to gain a complete understanding of Anambra Basin's hydrocarbon potential. The upper

Chidozie Izuchukwu Princeton Dim

princeton.dim@gmail.com; princeton.dim@unn.edu.ng

1 Department of Geology, Faculty of Physical Sciences, University of Nigeria, Nsukka, Enugu, Nigeria
Cretaceous strata of the southeastern Nigerian basin appears to be a challenging target for stratigraphic and structural interpretation and petroleum exploration due to the paucity or non-availability of subsurface data in the inland basins of Nigeria, especially the Anambra Basin. As part of an ongoing review of the petroleum prospectivity of the Anambra Basin, this study utilizes surface data obtained from various outcrop locations in furthering our understanding of the key elements (encompasses source, reservoir, and seal or cap rocks) of the petroleum system and proffering better exploration guide within the Anambra Basin of Nigeria. These key elements of petroleum systems, which were evaluated by the interpretation of surface data forms the basis for assessing the hydrocarbon prospectivity of most sedimentary basins around the world. In addition, the formation of an active petroleum system involves processes such as trap formation and generation-migration-accumulation of hydrocarbons (Magoon and Dow 1994). Outcrops of the Campanian to Maastrichtian rocks of the Anambra Basin studied includes the 9th Mile, Milliken-Onyeama Hills, Enugu-Onitsha

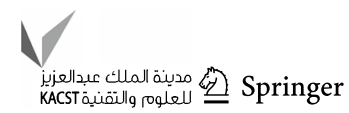


Flyover, Four Corner Ozalla Junction, Ihube-Okigwe and Afikpo-ABSU-Uturu sections of southeastern Nigeria, covering (Fig. 1).

\section{Geologic framework}

The Anambra Basin is situated at the southwestern extremity of the Benue Trough. It is bounded to the west by the Precambrian basement complex rocks of western Nigeria, to the east by the Abakaliki Anticlinorium, and to the south by the northern portion of the Niger Delta petroleum province (Fig. 1). The tectonic evolution of the sedimentary basins of southeastern Nigeria started with the break-up and separation of the African and South American plates in the Late Jurassic, which was initiated by the Y-shaped, RRR triple-junction ridge system (Burke et al. 1971; Benkhelil 1982). Basin fills were controlled by three mega-tectonic cycles, which resulted in the displacement of the depositional axis of the main basin giving rise to three successive basins, namely, the Abakaliki-Benue Trough, the Anambra Basin, and the Niger Delta Basin (Murat 1972; Benkhelil 1986). The Santonian compressional uplift of the Abakaliki-Benue Trough, with its resultant sediment folding, displaced the depocentre from the Abakaliki Basin, to the Anambra Basin and finally, in the Tertiary, to the Niger Delta (Nwajide and Reijers 1996).

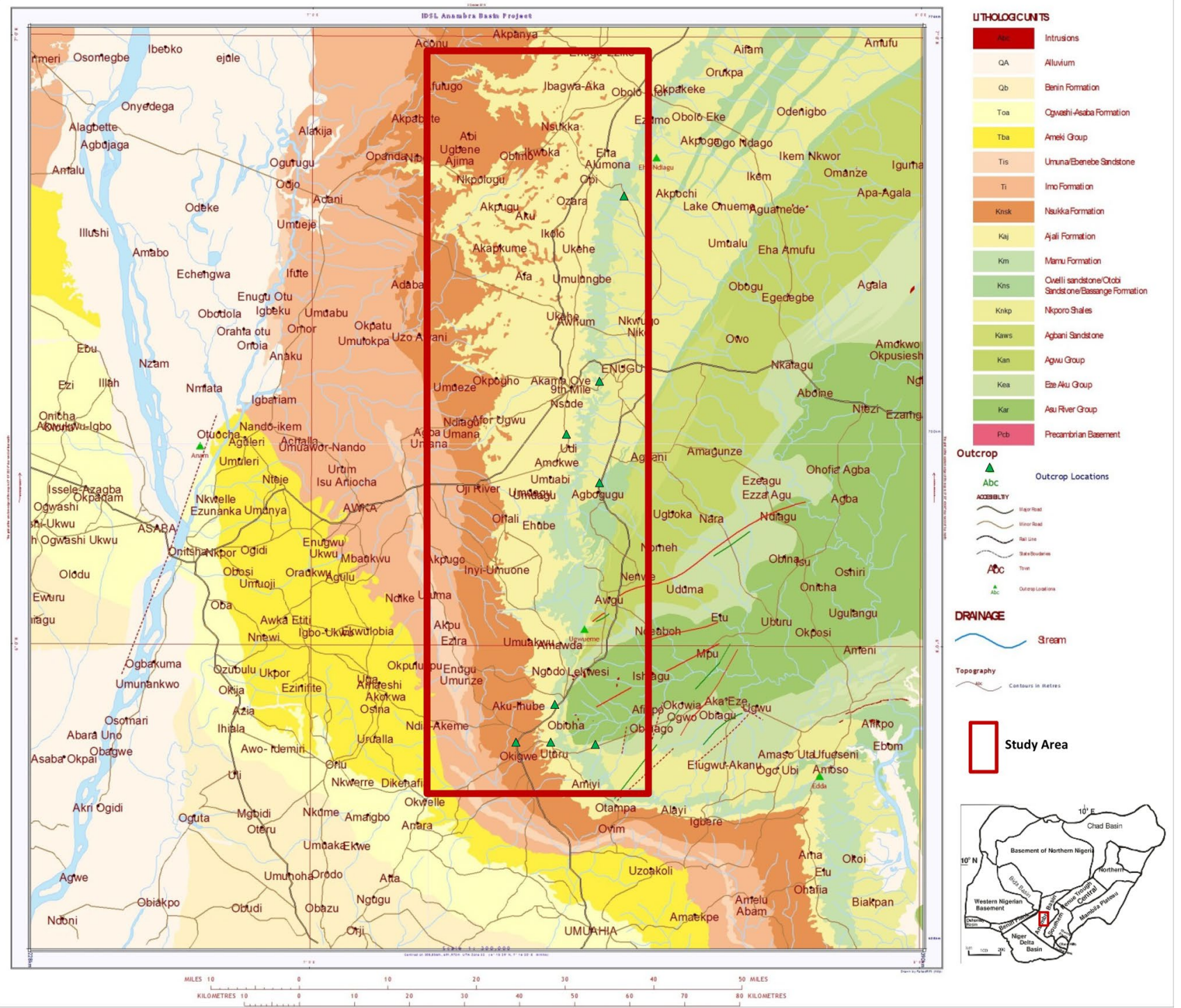

Fig. 1 Geologic map of Southeastern Nigeria showing the spatial distribution of outcrop locations in the study area (modified from UNN-IDSL Project Map 2012). Inset map of Nigeria with outlines of geology showing the Anambra Basin 
The Anambra Basin consists of four lithostratigraphic units (Fig. 2; Murat 1970; Ekweozor 1982; Hoque and Nwajide 1985; Petters 1991; Ojoh 1992; Obaje et al. 1999; Dim et al. 2017). Sedimentation in the Anambra Basin began in the Campanian with a short marine transgression depositing the units of the Nkporo Group (Owelli Formation, Nkporo Formation, Enugu Formation), which consists of carbonaceous shales and sandstone members of deltaic origin (Nwajide and Reijers 1996; Odunze and Obi 2013). This unit is overlain by the coal-bearing Mamu Formation deposited in the Late Campanian to Early Maastrichtian, at the beginning of a regressive phase. It consists of alternating sandstones, sandy shales and mudstones, with interbedded sub-bituminous coal seams (Akande et al. 2007). Overlying the Mamu Formation is the Ajali Formation, which comprises predominantly interbeds of clay laminae and the Nsukka Formation of mid-to-late Maastrichtian age. The Nsukka Formation consists of dark shales and sandstones, with thin coal seams that mark the beginning of the transgression that led into the formation of the Niger Delta Basin in the early Paleogene (Nwajide and Reijers 1996). The sediment packages were deposited during a regressive cycle (relative sea-level fall) within fluvio-tidal, deltaic, shelfal and marine settings (Dim et al. 2017).

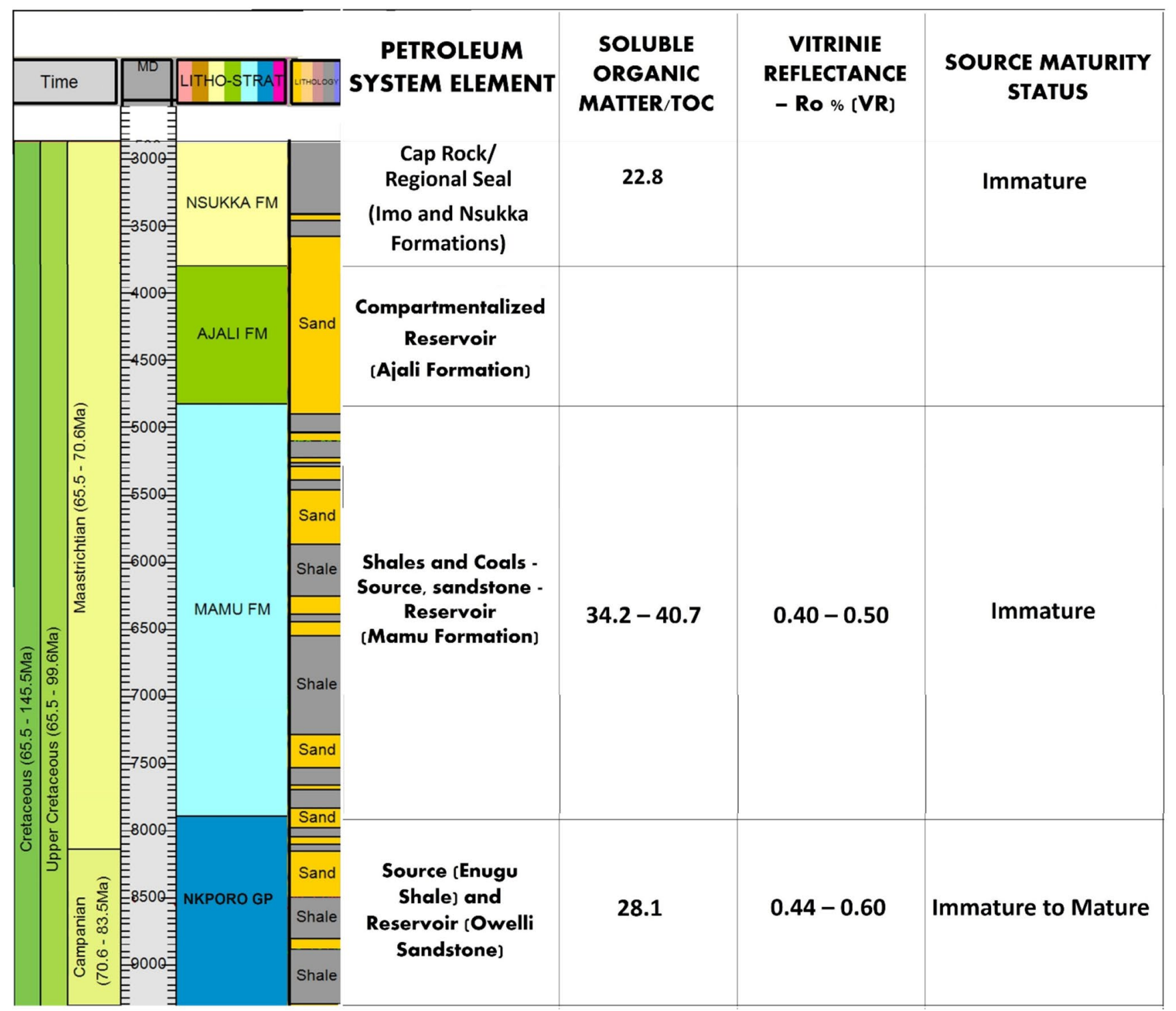

Fig. 2 Stratigraphic chart and petroleum system elements of various lithostratigraphic units in the Anambra Basin (after Ekweozor 1982; Obaje et al. 1999; Dim et al. 2017) 


\section{Methodology}

Representative outcrops of the lithostratigraphic units in the Anambra Basin were visited and studied. Detailed outcrop studies, examination of geological structures, and sedimentological logging (systematic measuring and recording) of representative outcrop sections were carried out (Fig. 3a-d). Lithologies were identified and described based on rock type, colour, grain size and textural characteristics with associated biogenic, syn-sedimentary and depositional structures (Figs. 4, 5, 6, 7, 8, 9, 10). Based on the identified facies, potentially key elements of the petroleum system(s) are outlined and discussed.

\section{Results and discussion}

\section{Outcropping lithostratigraphic units}

\section{Enugu Formation}

Three representative outcrops of the Enugu Formation (the oldest lithostratigraphic unit in the Anambra Basin) were studied and these include; (1) a road-cut exposure near flyover section along Enugu-Onitsha road Enugu, that consist of over $20 \mathrm{~m}$ thick sediment package (Fig. 3a). The lower section of this outcrop is characterized by thick, deep greyto-black shale with siltstone and sandstone interstratification (Fig. 4a, b). Concretional bands and nodules occur within the shale units (Fig. 4b). The middle section is made up of rapid alternation of shale, siltstone and fine-grained sandstone (heterolithic interval), whereas the upper section is characterized by a fairly thick shale package with ironstone concretional bands (Fig. 4c, d). Bioturbation is common in these siltstones and fine-grained sandstones. Structural features in this section include anastomosing sets of vertical joints, northeast-southwest trending faults (with a throw of about $2 \mathrm{~m}$ ) in the heterolithic and shale intervals (Fig. 4a, d). The fault in this section exhibits attribute of a listric fault which has a curvilinear slip plane. There is also evidence of clay filling (clay smear) within the fault zone. Nwajide (2013) identified this structure as growth fault, which is a deformational sedimentary structure that develops in response to gravitational instability due to sediment loading, especially on plastic and ductile shales. Sediment package is thicker at the down-thrown section (hanging wall) and thinner at the up-thrown section (footwall); (2) Amagu section, a road-cut exposure along Enugu-Port Harcourt expressway, is characterized by thick shale intervals with basal and top heterolithic intervals (interlamination of fine-grained sand, siltstone and shale unit). There is also a normal fault structure exposed at this section with observable throw of $1.9 \mathrm{~m}$ (Fig. 4e); and (3) thick shale package (about $4 \mathrm{~m}$ ) exposure
Fig. 3 Sedimentological log showing sedimentary successions at various representative outcrops of lithostratigraphic units in the Anambra Basin. a Enugu Formation exposed at a flyover across Enugu-Onitsha road, SE Nigeria. b Mamu Formation unit exposed at Udi by-pass (lower section of) along Udi-Four Corner road, Enugu State, SE Nigeria. c Large-scale planar and herringbone crossbedding in sandstone units and interlaminated clay bands of Ajali Formation exposed at Onyekaba quarry, Okigwe, along Enugu-Port Harcourt expressway, SE Nigeria. d Nsukka Formation exposed at Ikpankwu quarry, Okigwe, off Enugu-Port Harcourt road, SE Nigeria

at Four Corner Junction, Ozalla road-cut (about $3 \mathrm{~km}$ north of the University of Nigeria, Teaching Hospital) along Enugu-Port Harcourt expressway, southeastern Nigeria, containing sandstone/siltstone/shale heterolithic interbeds. The lower section of this outcrop shows a structural displacement due to a normal fault with a sharp diagonal truncation of the sediment package (Fig. 4e). The sandstones, heterolith and carbonaceous shale of Enugu Formation represent sediment packages deposited in fluvio-deltaic, delta front and estuarine environments (Table 1; Obi and Okogbue 2004; Odunze and Obi 2013).

\section{Mamu Formation}

The representative outcrops of this Mamu lithostratigraphic unit are found along road-cut exposures on a narrow NE-SW trending ridge, along Udi by-pass road and Enugu-Onitsha express road (Fig. 3b). The ridges are discontinuous, probably due to denudation processes. Sedimentary units are nearly horizontal (maximum dips of $5^{\circ}-7^{\circ}$ to the southwest) which indicate that the area was largely unaffected by major tectonic deformation. Bed thicknesses range from 0.25 to $2.5 \mathrm{~m}$. Lithologies include very fine and fine- to medium-grained sandstone, siltstone, claystone, shale, silty-shale, black carbonaceous/coaly shale, coal and heteroliths (Fig. 5a-i). The logged sections are characterized by repeated cycles of sandstone, heterolith, carbonaceous shale and coal units. The coal beds show columnar joint structures and exhibit dull-to-bright lustre (Fig. 5c, h). These are found occurring within heterolithic and carbonaceous sand and shale intervals. Slightly deformed primary sedimentary structures, such as hummocky and swaley cross-stratification, and fractures are seen occurring on the fine-grained sandstone units of the upper parts of the Mamu Formation (Fig. 5d). Other primary sedimentary structures observed include parallel and wave-ripple laminations, tabular and trough cross-beds, with horizontal and vertical burrows of varying bioturbation intensities. The coal, carbonaceous shale, sandstone, siltstone and heterolithic facies of Mamu Formation represent sediment packages deposited in swamps and lagoons, barrier islands, shoreface, offshore-transition zone, and offshore environments (Table 1; Adedosu et al. 
SEDIMENTARY SUCCESSION AT ENUGU-ONITSHA ROAD FLYOVER (ENUGU FORMATION)
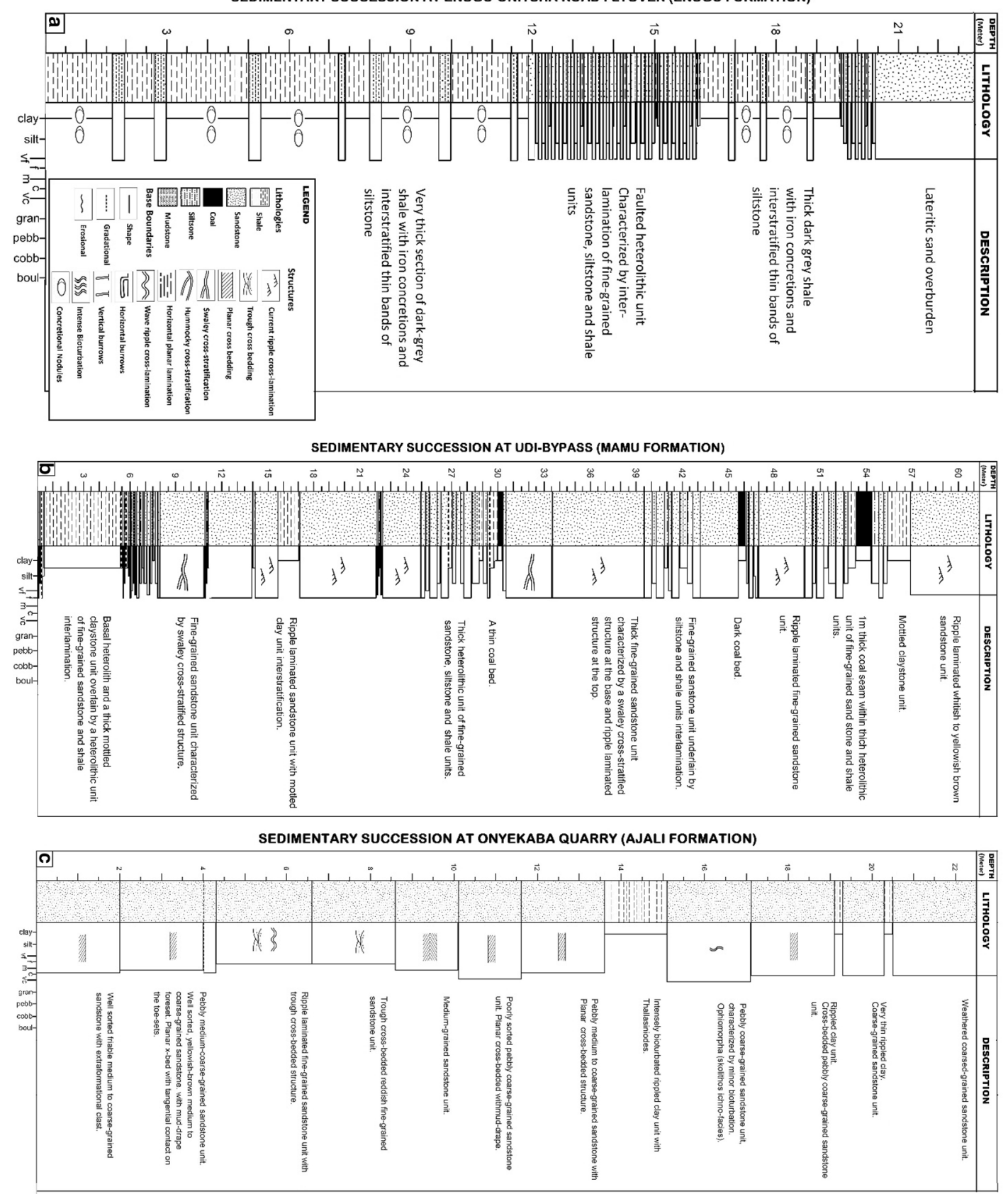

SEDIMENTARY SUCCESSION AT IKPANKWU QUARRY (NSUKKA FORMATION)

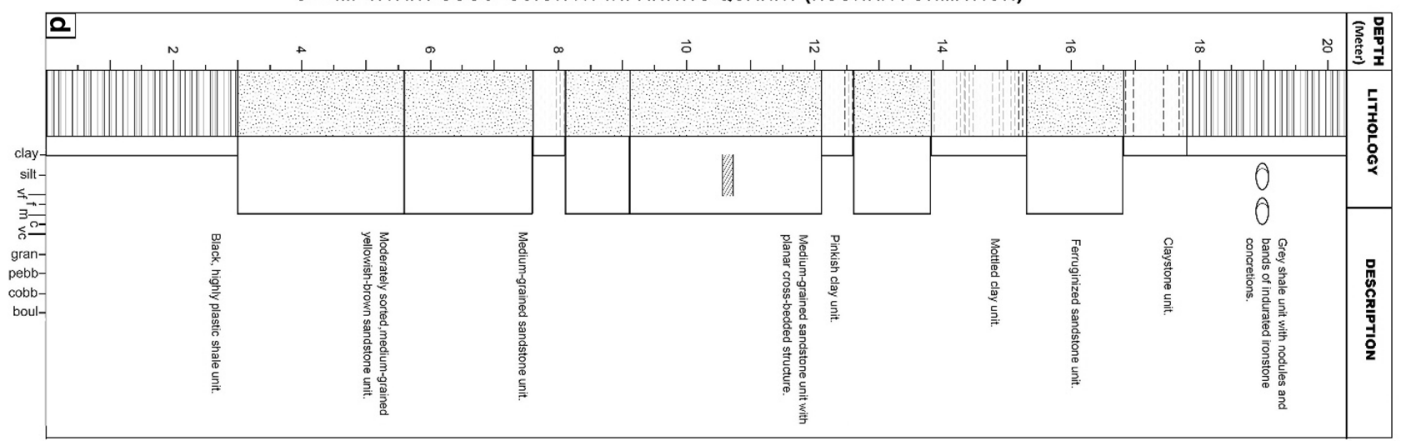



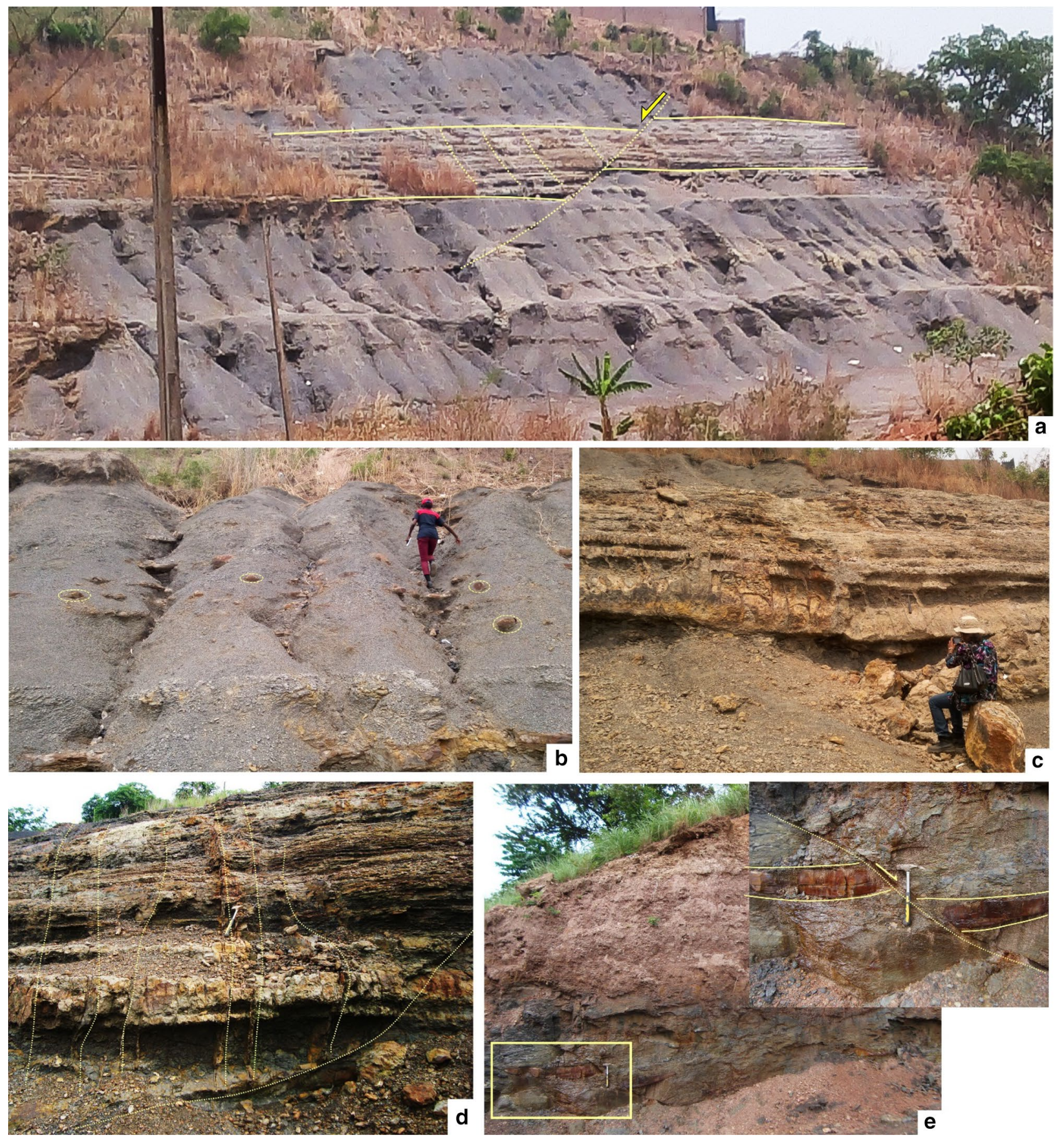

Fig. 4 Outcrops of Enugu Formation. a A road-cut exposure of the thick shale characterized by siltstone/sandstone interstratification in the Enugu Formation, near Onitsha road flyover in Enugu. Note the heterolithic (interstratification of sandstone, siltstone and shale) package at the middle section with evidence of a listric fault, typical of growth fault system. b A close-up of the upper section of Fig. 4a showing thick shale with siltstone interbeds and scattered ironstone concretion nodules, marked by dotted lines. c Disintegrated rock fragments and boulders from the heterolith showing healed fractures and intensely burrowed surfaces, near a flyover at Enugu along EnuguOnitsha road, SE Nigeria. d A close-up of the sandstone/siltstone/ shale heterolithic unit shown in Fig. 4a anastomosing fault and joint structures (indicated by yellow dotted lines). e Thick shale package of Enugu Formation partly weathered at the upper section (with an inset of faulted block at the bottom left section) exposed a Four Corner Junction at Ozalla (about $3 \mathrm{~km}$ north of the University of Nigeria, Teaching Hospital) along Enugu-Port Harcourt expressway, SE Nigeria. (Note scale: hammer $=0.3 \mathrm{~m}$ and geologist $=1.8 \mathrm{~m}$ ) 

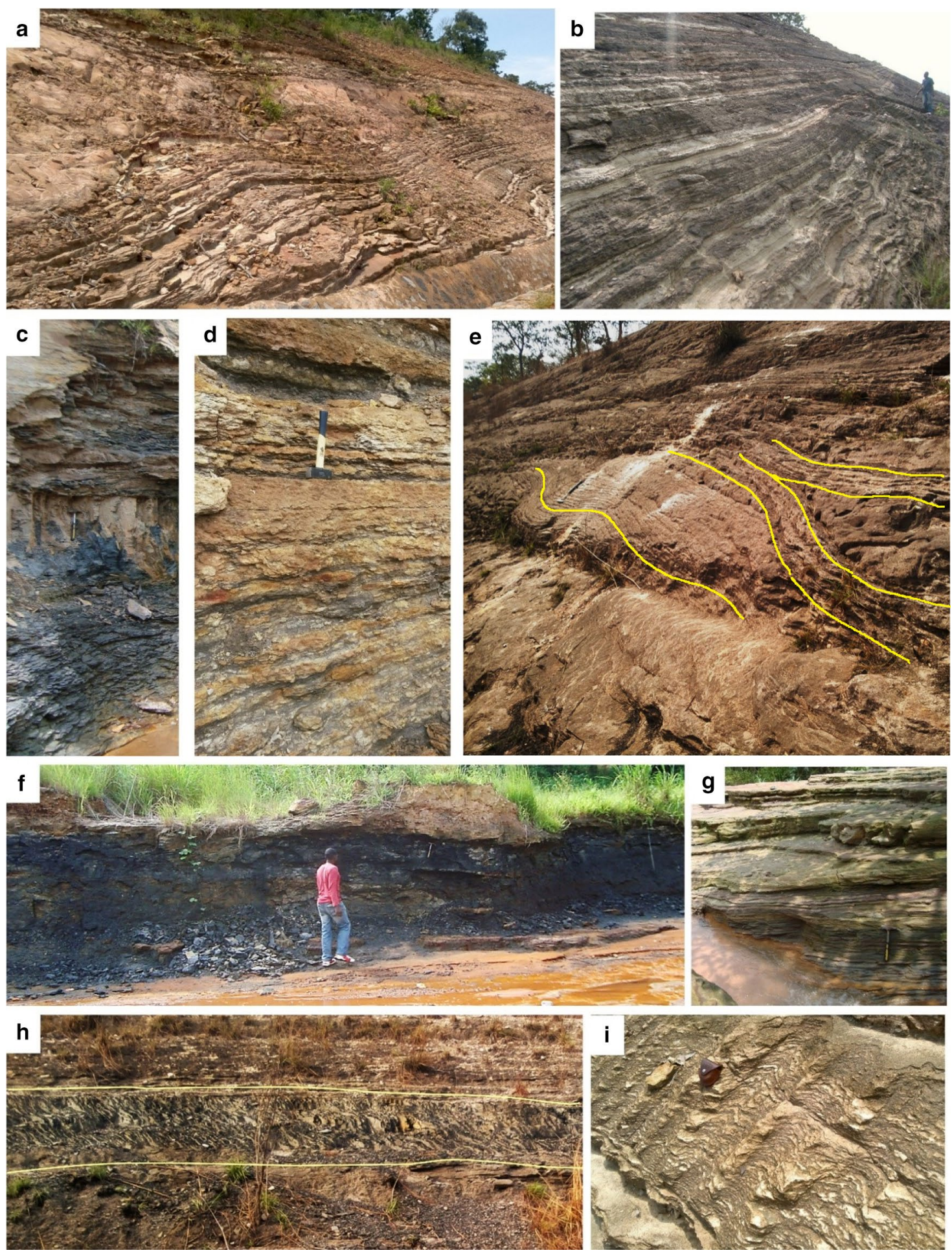

Fig. 5 Outcrops of Mamu Formation. a Road-cut section showing wave ripple-laminated sandstone unit of Mamu Formation, exposed long OpiNike by-pass, SE Nigeria. b Relatively inclined ripple-laminated to parallel-laminated fine-grained sandstone unit associated with possible gliding surfaces exposed at Onyeama Hill section along Enugu-Onitsha road, SE Nigeria. c Coal bed within a heterolith (interlaminated sandstone, siltstone and shale) at Iva valley section, along Enugu-Onitsha road. d Heterolith showing ripple laminated sandstone, siltstone and dark-gray shale units exposed at ABSU-Afikpo road, SE Nigeria. e Swaley stratified/hummocky cross-stratified sandstone unit exposed on Onyeama Hill section $1.5 \mathrm{~km}$ from Proda Bridge (swales indicated by yellow stripes). f Weathered coaly shale unit belonging to Mamu Formation exposed at Iva valley, off Enugu-Onitsha road. g Heterolithic interval within Mamu Formation exposed at Iva valley, off Enugu-Onitsha road. h Coal seam (indicated by yellow line) occurring with carbonaceous laminated sandstone units in the Mamu Formation exposed at Onyeama Mine section, along Enugu Onitsha Express Road, SE Nigeria. i Modified wave ripplelaminated sandstone unit exposed along Opi-Nike road, SE Nigeria (note scale: hammer $=0.3 \mathrm{~m}$ and geologist $=1.8 \mathrm{~m}$ )

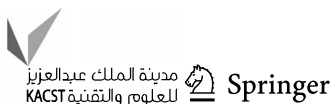



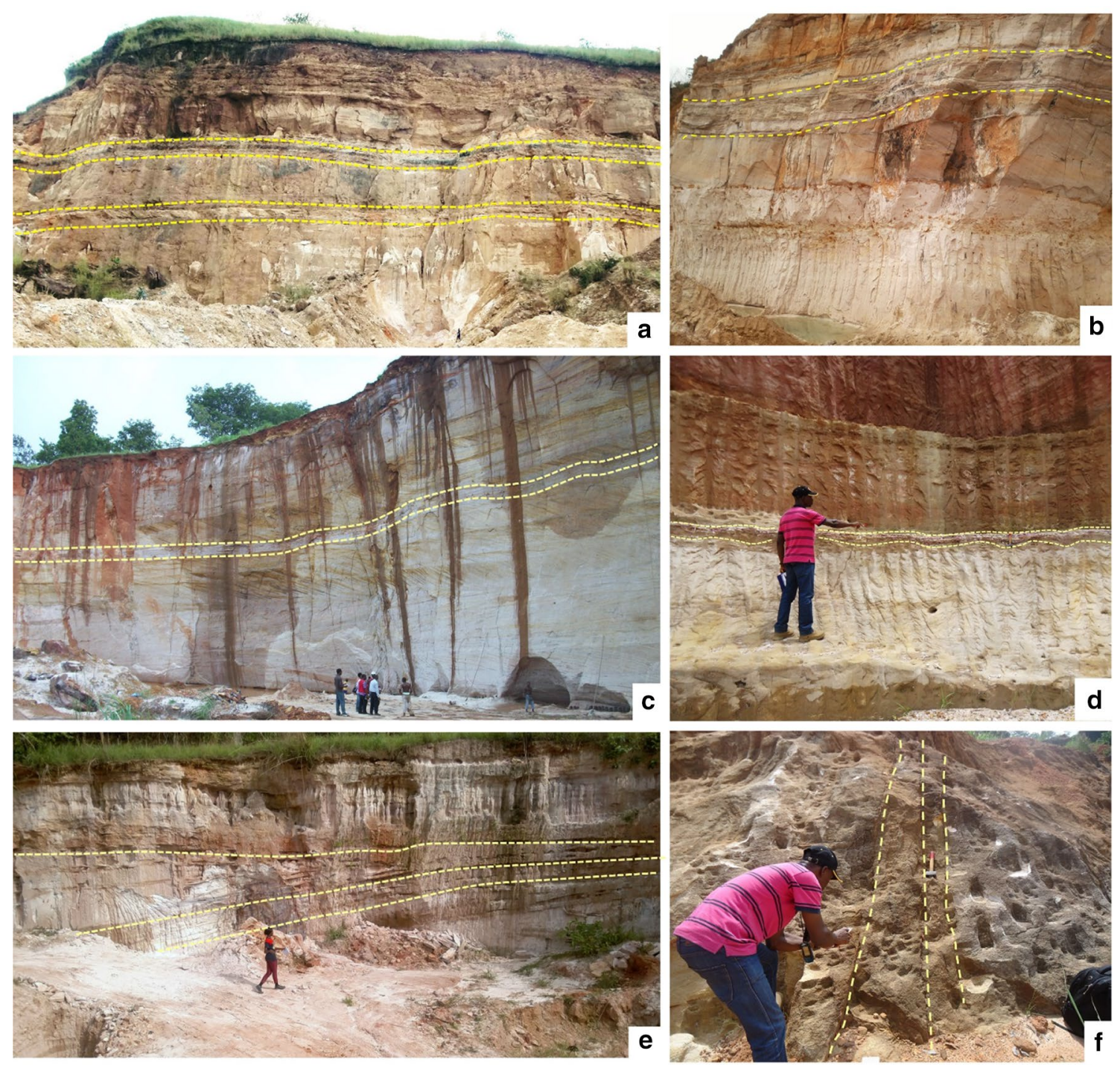

Fig. 6 Outcrops of Ajali Formation. a Very thick sandstone characterized by interstratified thin clay bands (indicated by yellow stripes) exposed at a quarry section in Alabama Hills, behind ABSU, off Okigwe-Afikpo road, SE Nigeria. b Thick sandstone unit with interlaminated bands of clay (indicated by yellow stripes) at the upper section of Ajali Formation exposed at a quarry section off ABSUOkigwe-Afikpo Road, SE Nigeria. c Quarry section showing thick sandstone package of the Ajali Formation at Ugwuabo-Isiukwuato, with presence of large-scale planar and herringbone cross-bedding with reactivation surfaces and observable band of clay (indicated

2014; Onyekuru and Iwuagwu 2010; Odumodu 2014; Dim et al. $2018 \mathrm{~b}$, in press).

\section{Ajali Formation}

Outcrops of the Ajali lithostratigraphic unit are exposed at quarry sections in Alabama Hills, behind Abia State University (ABSU), Uturu-Okigwe-Afikpo Road, Ugwuabo-Isiukwuato area, Ihube-Onyekaba-Okigwe by yellow stripes). d Sandstone units of Ajali Formation exposed at Onyekaba. Note geologist pointing at thin highly burrowed clay bed (see Fig. 9h for a close-up). e Thick sandstone unit with basal section showing cross-stratified units of clay bands (indicated by yellow stripes) and sandstone interstratification exposed at Ihube quarry section along Enugu-Port Harcourt expressway, SE Nigeria. f Joint structures (indicated by yellow dotted lines) on a sandstone units of Ajali Formation exposed at Onyekaba quarry along Enugu-Port Harcourt expressway, SE Nigeria (note scale: hammer $=0.3 \mathrm{~m}$ and geologist $=1.8 \mathrm{~m}$ )

area and at Enugu-Onitsha road (near 9th Mile area) all in southeastern Nigeria (Fig. 6a-f). Exposed sections are made up of poorly cemented, very thick sandstone units characterized by interstratified thin clay bands (Fig. 3c). Sandstone grain size varies from fine, medium, coarse, to partly pebbly, and are characterized by large-scale planar and herringbone cross-bedding with reactivation surfaces (Fig. 6c). Foresets of cross-beds laminae exhibit normal grading and are characterized by mud drapes. Evidence of 

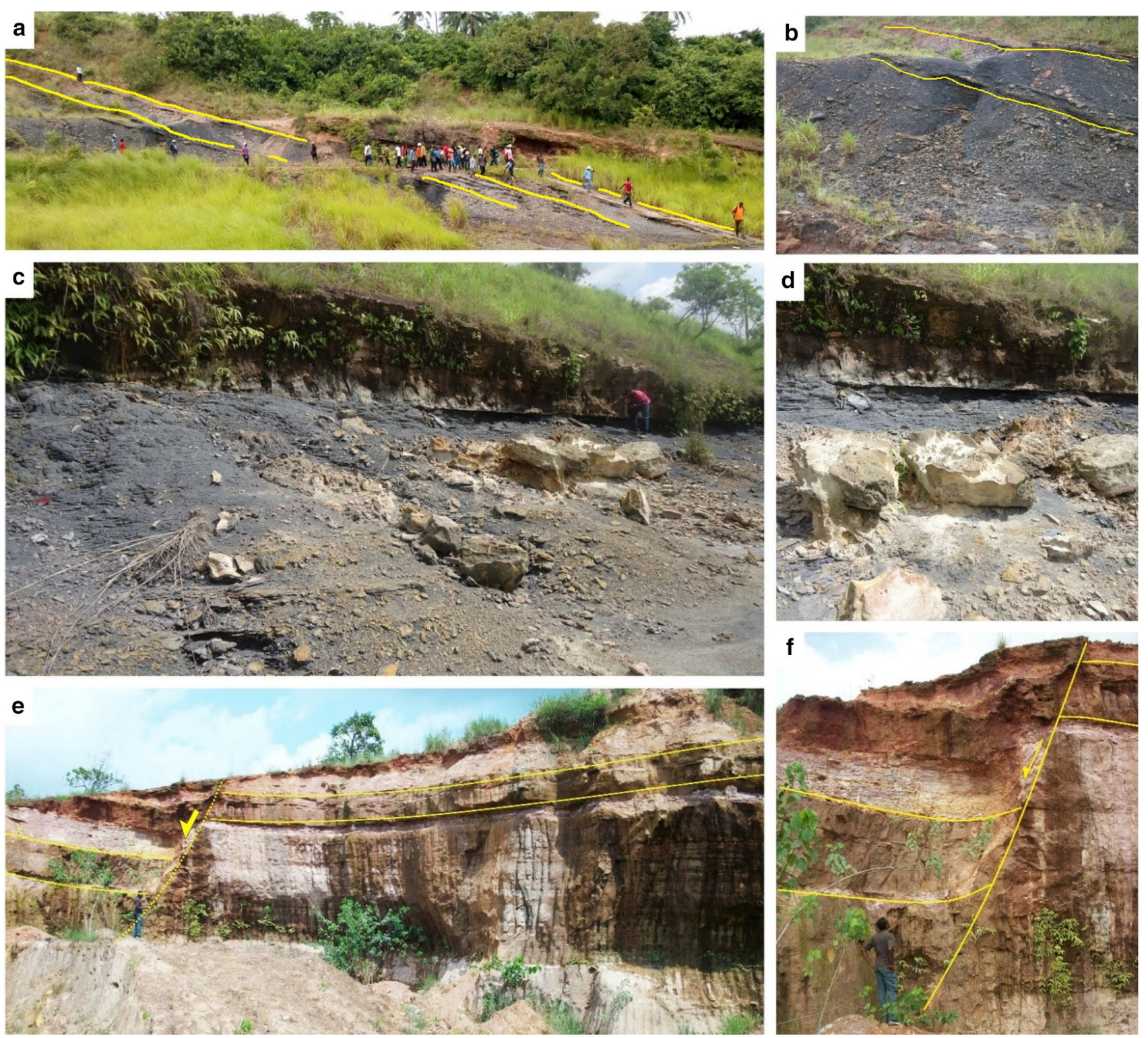

Fig. 7 Outcrops of Nsukka Formation. a Tilted shale units with siltstone interbeds (indicated by yellow stripes) of Nsukka Formation, exposed at Umuasua, off Isuikwuato-Arochukwu road, SE Nigeria. b A close-up of the tilted shale units with siltstone interbeds (indicated by yellow stripes) in Fig. 7a. c Thick shale overlain by sandstone in Nsukka Formation, outcropping at a road-cut section, km 76 on both side of Enugu-Port Harcourt expressway. d A close-up showing boulder of sandstones from the overlying sandstone unit and sharp contact

bioturbation is seen in sandstones, which distorts the primary sedimentary structures. Clay band intervals are fossilized and intensely burrowed, especially at the Onyekaba quarry section (Figs. 6d, 9h). Other sedimentary structures are wave-rippled surfaces well preserved at the Onyekaba section, and occasional joints within consolidation sandstones (Fig. 6f). The sandstone and laminar claystone facies of Ajali Formation represents sediment packages between the basal shale and overlying sandstone unit in Nsukka Formation. e Normal fault system at Ikpankwo quarry, off Enugu-Port Harcourt express expressway (note, arrow indicates displaced/juxtaposed fault blocks). f A close-up of the normal fault showing the down-thrown (hanging wall) and up-thrown (footwall) block exposed at Ikpankwo quarry, off Enugu-Port Harcourt express expressway, SE Nigeria (note scale: hammer $=0.3 \mathrm{~m}$ and geologist $=1.8 \mathrm{~m}$ )

deposited in fluvio-tidal channel and tidal shelf environments (Table 1; Ladipo 1986, 1988).

\section{Nsukka Formation}

Outcrops of Nsukka lithostratigraphic unit are exposed on road-cut and quarry section of Umuasua, off Isuikwuato-Arochukwu road, Okigwe, near a church along the 
Fig. 8 Outcrops of potential source and seal rocks in Anambra Basin. a Ironstone/siltstone bands and concretional nodules exposed in basal shale units of Mamu Formation exposed near a flyover at Enugu along Enugu-Onitsha road, SE Nigeria. b Dark-gray plastic shale of Nsukka Formation exposed at basal section of Ikpankwu quarry, off Enugu-Port Harcourt express expressway, SE Nigeria. c Coal bed of Mamu Formation exposed at the base of thick carbonaceous sandstone at Udi by-bass, SE Nigeria. $\mathbf{d}$ Close-up of anastomosing joint that could serve as pathway for fluid migration, occurring within the basal shale unit. e Coal bed within the Mamu Formation exposed at Proda Section, road-cut section along Enugu-Onitsha road (note scale: hammer $=0.3 \mathrm{~m}$ )
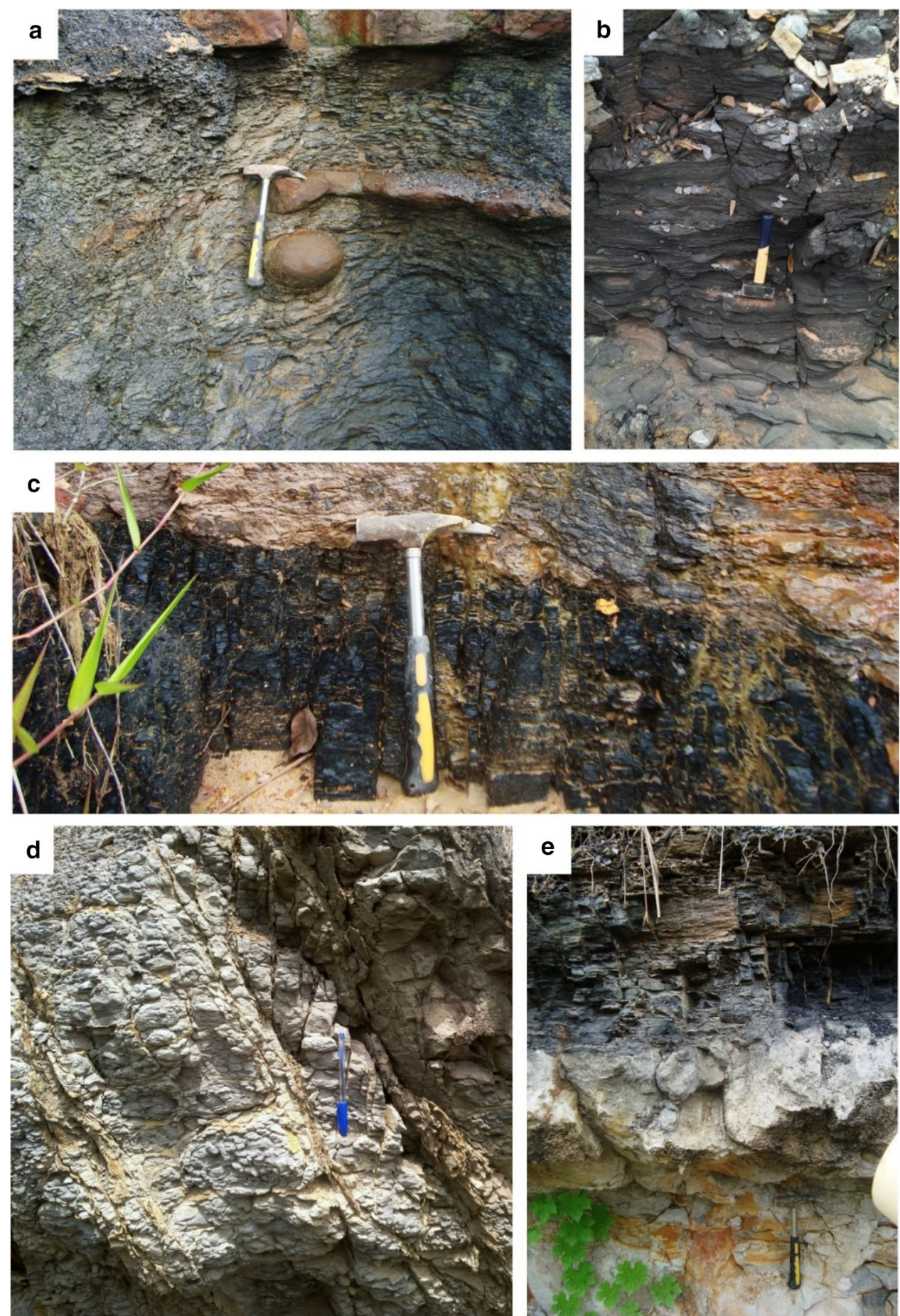

Enugu-Port Harcourt expressway, and Ikpankwo quarry, off Enugu-Port Harcourt express expressway in southeastern Nigeria (Fig. 7a-f). Lithologies include thick, fine- to medium-grained sandstone and dark shale unit (usually there are sharp contacts between shale and sandstone unit). The Nsukka Formation is also characterized at it upper section by thick shales with sandstone/siltstone interstratification. These are seen at the upper section of Umuasua and Okigwe road-cut sections (Fig. 7a-d). A prominent normal fault system is also exposed at Ikpankwo quarry showing the downthrown and upthrown blocks component (Fig. 7e, f). There are also primary sedimentary structures such as current-rippled surfaces and intensely bioturbated and burrowed sandstone units at Umuasua section. The occasional coal, sandstone, shale and heterolith of Nsukka Formation represents sediment packages deposited in 

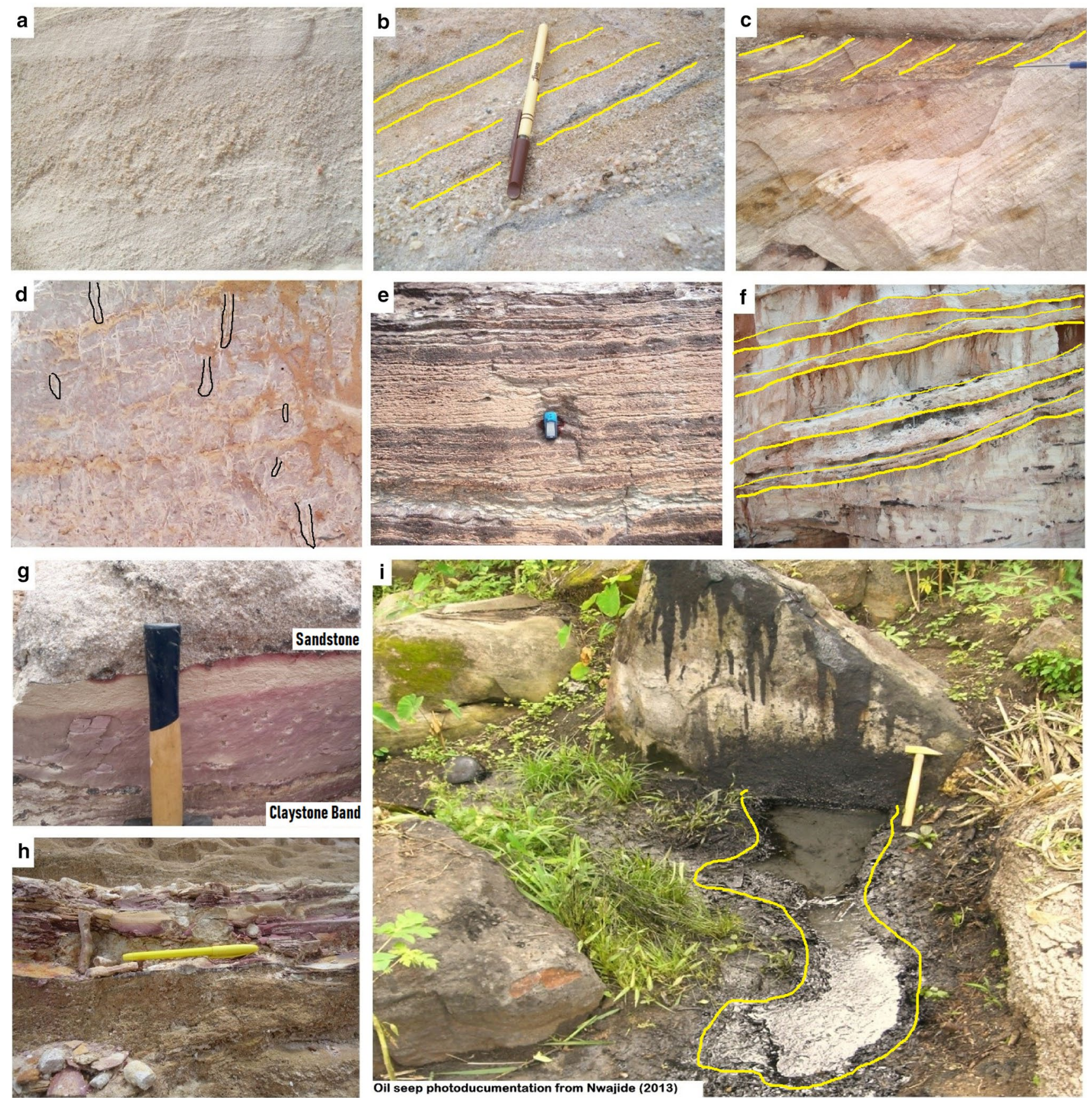

Fig. 9 Outcrops of potential reservoir rocks in Anambra Basin. a A clean medium-grained sandstone of Ajali Formation exposed at a quarry section in Alabama Hills, behind ABSU, off Okigwe-Afikpo road, SE Nigeria. b Cross-bedded sandstone with normal grading at the foreset of lamina (indicated by yellow stripes) exposed within Ajali Formation at a quarry section in Alabama Hills, behind ABSU, off Okigwe-Afikpo road, SE Nigeria. c Cross-bedded sandstone of Ajali Formation showing mud drape on foreset lamina (mud could act as baffle affecting reservoir quality), exposed at a quarry section in Alabama Hills, behind ABSU, off Okigwe-Afikpo road, SE Nigeria. d Intensely bioturbated sandstone (with vertical burrows indicated by black line traces) unit of Ajali Formation exposed at a quarry section in Alabama Hills, behind ABSU, off Okigwe-Afikpo road, SE Nigeria. e Ripple laminated to parallel laminated sandstone unit of Mamu
Formation exposed at Onyeama Hill section along Enugu-Onitsha road, SE Nigeria. $\mathbf{f}$ A close-up of Fig. 6e, a thick sandstone unit with basal section showing cross-stratified units of clay bands and sandstone interstratification exposed at Ihube quarry, Okigwe section along Enugu-Port Harcourt expressway, SE Nigeria. g A close-up of a boulder showing shape contact between the basal clay and sandstone units exposed at a quarry section off ABSU-Okigwe-Afikpo Road, SE Nigeria. h A close-up of Fig. 6f, showing the clay band with evidence of intensely burrowed surfaces and bioturbation possibly forming a barrier between the underling and overlying. i Oil seep (coverage indicated by yellow stripes) in Owelli Sandston at foot of Enugu Cuesta near Ugwueme village- thought to have been sourced from shales of Awgu Formation of Abakaliki Basin (underlying the Enugu Formation of Anambra Basin) 
Fig. 10 Outcrop of structural traps in Anambra Basin. a The middle section of Fig. 2a, showing a heterolithic interval with well-developed growth fault in the Enugu Formation exposed near Onitsha road flyover in Enugu, SE Nigeria (note rollover structures on both hanging wall and the footwall). A closeup of the down-thrown block of the faulted section. b Road-cut exposure of the Enugu Formation showing normal fault system on thick shale with siltstone interbeds, geologists positioned on the handing wall and footwall (outcrop at Amagu along Enugu-Port Harcourt expressway, SE Nigeria). c A close-up of the bottom left showing a normal faulting of thin siltstone/ ironstone and shale package in Enugu Formation exposed at a road-cut exposure at Four Corner, Ozalla Junction, along Enugu—along Enugu-Port Harcourt expressway, SE Nigeria. d Faulted blocks showing juxtaposed siltstone/sandstone block on shale block, a road-cut exposure at Four Corner, Ozalla Junction, along Enugu—along Enugu-Port Harcourt expressway, SE Nigeria (note scale: hammer $=0.3 \mathrm{~m}$ and geologist $=1.8 \mathrm{~m}$ )
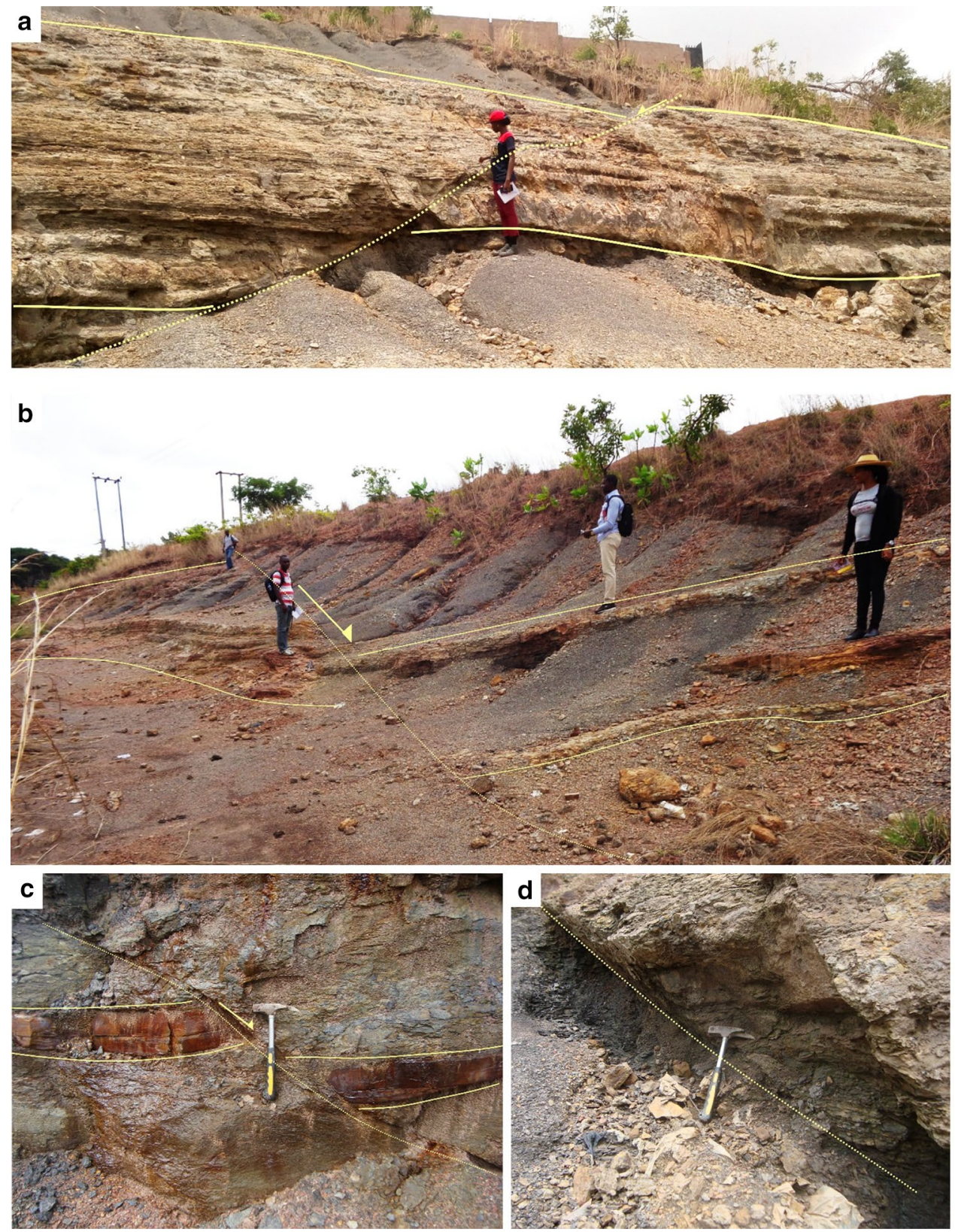

lagoon/bay, shoreface and offshore environments (Table 1; Mode 2004; Umeji and Nwajide 2007; Mode and Odumodu 2015).

\section{Elements of petroleum system}

Source rocks, traps, seals and reservoir rocks are the key elements of petroleum systems. In this paper, outcrop studies have been used to demonstrate the existence of potential essential elements that are in place and may favour hydrocarbon prospectivity in the Anambra Basin.

\section{Source rock presence and potential}

The source rock hosts the initial processes that are involved in the formation of oil and gas and contains the precursors of the kerogen-organic matter, which are broken down to form hydrocarbon, when subjected to high temperatures over a long period of time (Magoon and Dow 1994; Magoon and Beaumont 1999). The shales of the Nkporo Group, and the shales and coals of the Mamu and Nsukka formations provide possible source rock materials for hydrocarbon generation in the Anambra Basin (Fig. 8a-e). These shales are very thick and possess rich organic matter 


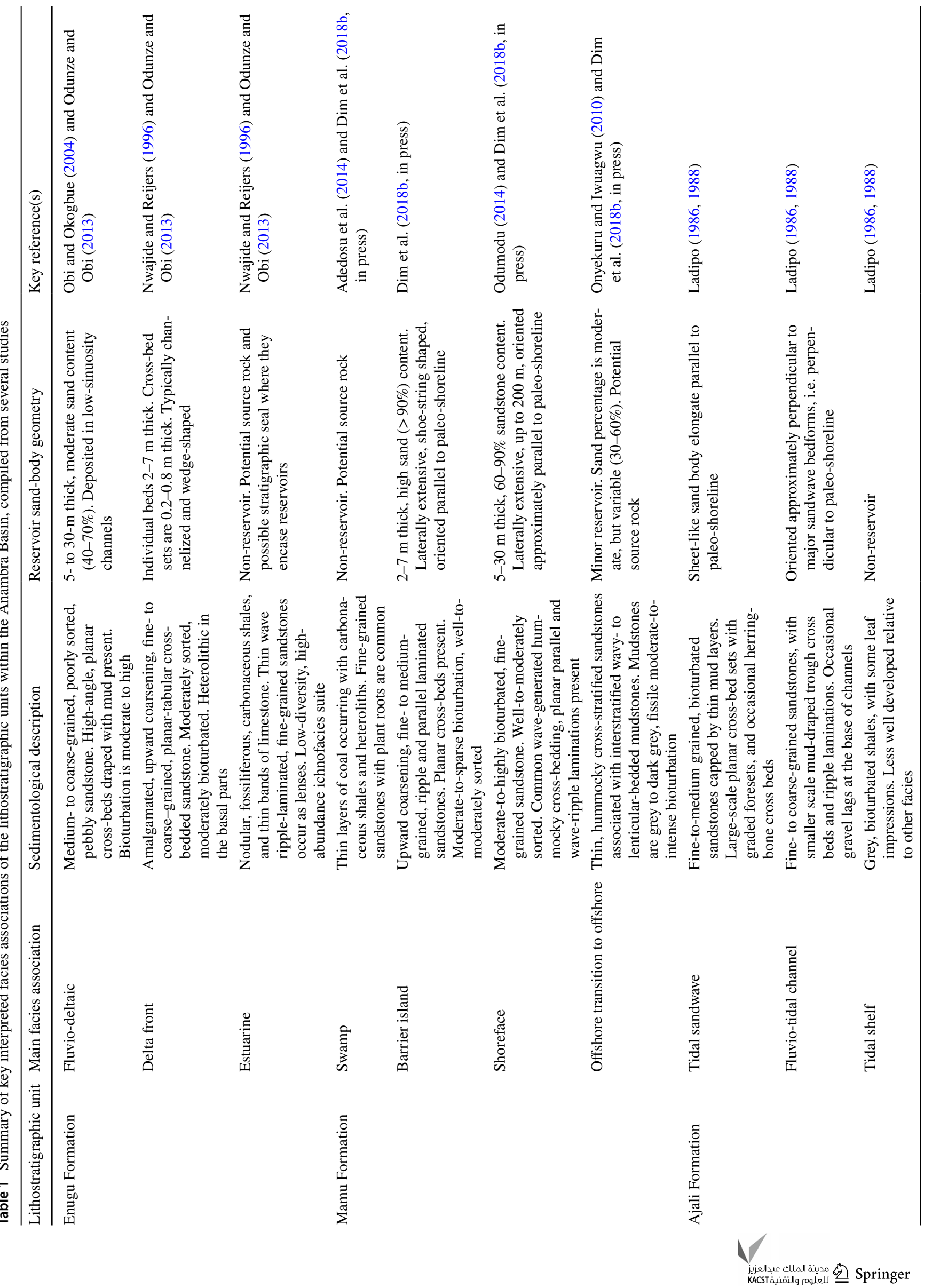


content (Fig. 8a, b; Agagu 1978). Organic geochemical and petrologic studies indicate that coal beds constitute major potential source rocks in the Anambra Basin (Obaje et al. 2004). Total organic content and rock-eval pyrolysis studies have placed shales of the Enugu Formation among the petroleum source rocks of the Anambra Basin (Obaje et al. 2004; Ehinola et al. 2005; Ojo et al. 2009). In the Anambra Basin, the coal beds in the Mamu Formation (Campanian-Maastrichtian) are dominated by huminites with fewer amounts of liptinites and inertinites, have total organic carbon (TOC) contents of as much as $60.8 \mathrm{wt} \%$, mean hydrogen index (HI) of $364 \mathrm{mg} \mathrm{HC/g}$ TOC, vitrinite reflectance (Ro) of $0.44-0.56 \%$, and $T_{\max }$ of $430-433{ }^{\circ} \mathrm{C}$. Biomarker data indicate a dominance of high molecular-weight $n$-alkanes, very high pristane/phytane ratios, pronounced odd-overeven predominance (OEP), a preponderance of $\mathrm{C} 29$ regular steranes, and relatively high contents of C28 (Obaje et al. 2004). Source rock data plots by Obaje et al. (2004) on the modified Van Krevelen diagram alongside biomarker and maceral data indicate fair-to-good source rock qualities. The vitrinite reflectance and $T_{\max }$ values showed that the coals are immature to marginally mature and have both oil and gas generative potentials (Ekweozor 1982; Akande et al. 2012). Previous studies have concluded that in deeper well sections away from the margins of the basin, the shales of the Nkporo Group and Mamu Formation are sub-mature to mature (Ekweozor and Gormly 1983; Obaje et al. 1999; Akaegbobi et al. 2000; Mode 2002).

\section{Reservoir presence and potential}

These are elements of petroleum system, which can accumulate hydrocarbons (oil or gas). Reservoir rocks are characterized by good porosity and permeability to accumulate and drain fluids. The sandstones, siltstones and the heterolithic intervals of the Enugu, Mamu, Ajali and Nsukka formations constitute potential reservoir packages (Fig. 9a-g). The thick Ajali Formation, which consists predominantly of fluviotidal sandstones, could represent the best potential reservoirs. These sandstones have fine-to-medium, sub-angular to rounded grains, and are moderately well-sorted quartz arenites, with high interparticle porosity $(>21 \%)$ and permeability values measured from surface outcrops, ranging from 7 to 55 darcy (Tijani and Nton 2009; Onyekuru et al. 2015). These sandstones have also been affected by bioturbation which could enhance or damage reservoir quality (e.g. Jackson et al. 2013; Fig. 9d, h). Also, thin interstratified clay bands (lamina) that are laterally extensive could act as fluid barriers leading to reservoir compartmentalization (Fig. 9f-h). Diagenetic alteration processes in sandstones of the Ajali Formation include moderate mechanical and chemical compaction evidenced by the dominance of point and line contacts and relative absence of mineral overgrowths, 
and kaolinite clay authigenesis, which suggests an early mesogenetic stage of diagenesis (Onyekuru et al. 2015). Sandstones of the Mamu Formation are also widespread and are important potential reservoirs (Table 1). They are moderately to well sorted, fine-to-medium grained, quartz arenites and feldspathic arenites (Mode et al. 2016). Diagenetic changes are mainly moderate-to-intense mechanical and chemical compaction (dominant suture contact between grains and quartz overgrowth), cementation (quartz and feldspar overgrowth), and the replacement of abundant feldspars to clay minerals, which have overall caused a mild reduction in the reservoir quality of the sandstones (Mode et al. 2016). A statistical analysis of the Enugu Formation, Mamu Formation, and the Ajali Formation in some parts of the basin, show that the porosities of possible reservoirs within these formations appear to have been destroyed by excessive cementation (Obaje et al. 1999; Onuoha 2005). Sequence stratigraphic correlation using subsurface wellbore data indicates that these reservoir package are laterally continuous except where structurally distorted (Dim et al. 2017).

\section{Seal presence and effectiveness}

Potential seal rocks in the Anambra Basin are mainly intraformational shales of the Mamu Formation, and quite extensive, regional shales of the Nsukka Formation. Few studies have investigated the sealing effectiveness of these shales. The study by Okogbue and Ugwoke (2012), based on the geotechnical indices of potential sealing layers, suggests that the shales of the Nsukka Formation have a relatively higher plasticity and toughness index than those of the Mamu Formation. This property predisposes the shales of the Nsukka Formation to deform in a ductile manner, which is a key attribute of good seal rocks (Downey 1994). Shales of the Mamu and Enugu Formations may deform in a brittle manner with associated joints and faults, when subjected to shear stress (Okogbue and Ugwoke 2012).

\section{Entrapment mechanisms}

Traps are structural or stratigraphic features that ensure that accumulated hydrocarbon are held in a fixed and firm position of seal and reservoir to avoid the escape of oil and gas to the surface. Outcrop exposures in the Anambra Basin have revealed the presence of fault (growth fault), which are similar to those found in available interpreted 2D seismic data of Anambra Basin and 3D subsurface seismic data of Niger Delta Basin (Figs. 4a, 7e, f, 10a, b; Abubakar 2004; Nwajide 2005; Dim et al. 2017, 2018a). These structures are believed to have formed due to response of sediment package to syn-sedimentary deformation (Obi and Okogbue 2004; Dim et al. 2017). These faults constitute structural traps, which together with stratigraphic traps could allow for accumulation of hydrocarbon on the both the footwalls and the hanging walls of fault structures (Fig. 10c, d).

\section{Implications for hydrocarbon exploration}

This study has given insight to the existence of key petroleum system elements and hydrocarbon occurrence through detailed photo-documentation of exposed rock units and oil seeps in the Owelli Sandstone (a lateral equivalent of the Enugu Formation) outcropping at the foot of Enugu Cuesta near Ugwueme village (Fig. 9i; Nwajide 2006, 2013). Outcrop studies indicate that these formations within the Anambra Basin consist of variable thicknesses of sediment packages. In addition, basin-wide correlation carried using well data reveals that the oldest formation (the Nkporo Formation) consists of a 300- to 600-m-thick sediment package while the overlying Mamu Formation consists of 600- to 1200 -thick sediments that are in turn overlain by 400- to 600-thick sediment units of the Ajali Sandstone. Sediments of the overlying Nsukka Formation are 20-50 m thick (Onuoha and Dim 2017). These sediments (sandstones and shales) constitute the reservoir; source and seal rock packages in the basin. Processes such as migration and accumulation could have been made possible by the presence of fractures occurring in the form of faults and anastomosing joints within the shales and sandstone units of Enugu Formation and Mamu Formation. Also, columnar joints present in coal beds of Mamu Formation could a provide pathways for petroleum migration (Fig. 8c-e). The shales of the Enugu and Mamu formations could offer excellent intraformational seal above the associated sandstones, as well as enhancing clay smearing within faults, while the shales of the Nsukka Formation are most extensive and represent regional seals (Tuttle et al. 1999; Dim et al. 2017). The Anambra Basin has the best potential within the Nigerian inland basins as it contain all the elements necessary for an active petroleum system: the marine shales of Nkporo Group and the Mamu Formation coals constitute good gas and oil source rocks; the clean sandstones of Ajali Formation and sandstones in the Mamu Formation form good reservoirs; and shales in the Nsukka Formations provide a regional seal (Obaje et al. 2004; Akande et al. 2007; Dim et al. 2017).

\section{Conclusions}

This study has shown the evidence of key petroleum system elements such as source, reservoir, traps and seals on outcropping lithostratigraphic units of the Anambra Basin. These exposures could help in extending our understanding of rock behavior and characteristics of the various formations in the subsurface. In addition, they can act as guide for hydrocarbon exploration and in locating

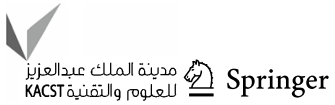


the most likely accumulations of petroleum in the Anambra Basin. The shales of Nkporo Group and the coals of Mamu and Nsukka formations could serve as good source rocks, whereas the sandstone and siltstone of the Mamu, Ajali and Nsukka formations could serve as potential reservoir rocks. The shales of the Nsukka Formation could serve as regional seals. The juxtaposed fault blocks due to structural deformation could serve as entrapment mechanism, whereas the joints in shales could provide possible migration pathways for hydrocarbons. In summary, detailed outcrop studies in the Anambra Basin have enabled understanding petroleum system elements that could be utilized in hydrocarbon exploration and also provided information for further researches in the southeastern part of the Anambra Basin of Nigeria.

Acknowledgements The authors are grateful to staff and students (undergraduate and postgraduate) of the Department of Geology who during their routine field work visits provided the opportunity to study rock exposures outlined in this paper. Thanks to Mr. L.M. Johnson of the Department of Geology, University of Ilorin, Kwara State, Nigeria; Mr. E.J. Adepehin of Wesley University of Science and Technology, Ondo State, Nigeria, and Mr. E.C. Anigbogu of the Department of Geology, Chukwuemeka Odumegewu Ojukwu University, Uli Campus, Anambra State, Nigeria, for their assistance during field studies.

Open Access This article is distributed under the terms of the Creative Commons Attribution 4.0 International License (http://creativeco mmons.org/licenses/by/4.0/), which permits unrestricted use, distribution, and reproduction in any medium, provided you give appropriate credit to the original author(s) and the source, provide a link to the Creative Commons license, and indicate if changes were made.

\section{References}

Abubakar MB (2004) Petroleum potentials of the Nigerian Benue Trough and Anambra Basin: a regional synthesis. Nat Resour 5:25-58

Adedosu TA, Sonibare OO, Tuo J, Ekundayo O (2014) The occurrence of Lacustrine depositional setting in the Mamu Formation, Anambra Basin, Nigeria. Energy Sources Part A Recovery Utilization Environ Effects 36(4):374-382

Agagu OK (1978) Geology and petroleum potentials of the Santonian to Maastrichtian sediments in the Anambra Basin, Eastern Nigeria. Ph.D. Thesis, University of Ibadan, Nigeria

Akaegbobi MI, Nwachukwu JI, Schmitt M (2000) Aromatic hydrocarbon distribution and calculation of oil and gas volumes in postSantonian shale and coal, Anambra Basin, Nigeria. In: Mello MR, Katz BJ (eds) Petroleum systems of south Atlantic margins, vol 73. American Association of Petroleum Geologists Memoir, Tulsa, pp 233-245

Akande SO, Ogunmoyero IB, Petersen HI, Nytoft HP (2007) Source rock evaluation of coals from the Lower Maastrichtian Mamu Formation, SE Nigeria. J Pet Geol 30(4):303-324

Akande SO, Egenhoff SO, Obaje NG, Ojo OJ, Adekeye OA, Erdtmann BD (2012) Hydrocarbon potential of Cretaceous sediments in the lower and middle Benue Tough, Nigeria: insights from new source rock facies evaluation. J Afr Earth Sci 64:34-47
Anyiam OA, Onuoha KM (2014) A study of hydrocarbon generation and expulsion of the Nkporo Shales in Anambra Basin, Nigeria. Arabian J Geosci 7(9):3779-3790

Anyiam OA, Onuoha KM, Jolly BA (2015) Play fairway evaluation of the Anambra Basin, Southeast Nigeria. Arabian J Geosci 8:539-546

Benkhelil J (1982) Benue trough and Benue chain. Geol Mag 119(2):155-168

Benkhelil J (1986) Structure and geodynamic evolution of the intracontinental Benue trough (Nigeria). Elf Nig. Ltd., Nigeria Bull Centres Rech Explor Prod Elf-Aquitaine (BCREDP) 12:29-128

Burke KC, Dessauvagie TFJ, Whiteman AJ (1971) Opening of the Gulf of Guinea and geological history of the Benue depression and Niger delta. Nat Phys Sci 233:51-55

Dim CIP, Onuoha KM, Okeugo CG, Ozumba BM (2017) Petroleum system elements within the Late Cretaceous and early Paleogene sediments of Nigeria's inland basins: an integrated sequence stratigraphic approach. J Afr Earth Sci 130:76-86

Dim CIP, Onuoha KM, Anyiam OA, Okwara IC, Oha IA, Okonkwo IA, Okeugo CG, Nkitnam EE, Ozumba BM (2018a) Analysis of petroleum system for exploration and risk reduction in the SouthEastern Inland Basins of Nigeria. Pet Coal 60(2):305-320

Dim CIP, Onuoha KM, Okwara IC, Okonkwo IA, Ibemesi PO (2018b) Facies analysis and depositional environment of the CampanoMaastrichtian coal-bearing Mamu Formation in the Anambra Basin, Nigeria. J Afr Earth Sci (in press)

Downey MW (1994) Hydrocarbon seal rocks. In: Magoon LB, Dow WG (eds) The petroleum system: from source to trap, vol 60 . American Association of Petroleum Geologists Memoir, Tulsa, pp 159-159

Ehinola OA, Sonibare OO, Falode OA, Awofala BO (2005) Hydrocarbon potential and thermal maturity of Nkporo Shale from lower Benue Trough, Nigeria. J Appl Sci 5:689-695

Ekweozor CM (1982) Petroleum geochemistry application to petroleum exploration in Nigeria's lower Benue Trough. J Min Geol 19:122-131

Ekweozor CM, Gormly JR (1983) Petroleum geochemistry of late Cretaceous and early tertiary shales penetrated by Akukwa- 2 well in the Anambra Basin, Southern Nigeria. J Pet Geol 6:207-216

Hoque M, Nwajide CS (1985) Tectono-sedimentological evolution of an elongate intracratonic basin (Aulacogen): the case of the Benue Trough of Nigeria. Niger J Min Geol 21:19-26

Jackson CA, Mode AW, Oti MN, Adejinmi K, Ozumba BM, Osterloff. P (2013) Effects of bioturbation on reservoir quality: an integration in reservoir modeling of selected fields in the Niger delta petroleum province. NAPE Bull 25(1):29-42

Ladipo KO (1986) Tidal shelf depositional model for the Ajali Sandstone, Anambra Basin, southern Nigeria. J Afr Earth Sci 5(2):177-185

Ladipo KO (1988) Paleogeography, sedimentation and tectonics of the upper Cretaceous Anambra Basin, southeastern Nigeria. J Afr Earth Sci 7(5-6):865-871

Magoon LB, Beaumont EA (1999) Petroleum systems. Chapter 3 in exploring for oil and gas traps. In: Beaumont EA, Foster NH (eds) AAPG treatise of petroleum geology. Handbook of petroleum geology, AAPG, Tulsa, pp 1-3

Magoon LB, Dow WG (1994) The petroleum system: from source to trap. Am Assoc Pet Geol Mem 60:655

Mode AW (2002) Hydrocarbon evaluation of Campanian-Maastrichtian strata within a sequence stratigraphic framework, Southeastern Anambra Basin, Nigeria. Unpublished Ph.D. Thesis, University of Nigeria, Nsukka, p 225

Mode AW (2004) Shallow marine transgressive sedimentation in the Nsukka Formation, Southeastern Nigeria, Nigeria. Niger Assoc Pet Explor Bull 17:28-41 
Mode AW, Odumodu CFR (2015) Lithofacies and ichnology of the Late Maastrichtian-Danian Nsukka Formation in the Okigwe area, Anambra Basin, Southeastern Nigeria. Arabian J Geosci 8(9):7455-7466

Mode AW, Anyiam OA, Anigbogu EC (2016) The effect of diagenesis on reservoir quality of Mamu Sandstone, Anambra Basin, Nigeria. J Geol Soc India 87:583-590

Murat RC (1970) Structural geology of the Cenozoic Niger Delta. In: Dessauvagie FJ, Whiteman AJ (eds) African geology, vol 4. University of Ibadan Press, Ibadan, pp 635-646

Murat RC (1972) Stratigraphy and palaeogeography of the cretaceous and lower tertiary in Southern Nigeria. In: Dessauvagie FJ, Whiteman AJ (eds) African geology. University of Ibadan Press, Ibadan, pp 251-266

Nwajide CS (2005) Anambra Basin of Nigeria: synoptic basin analysis as a basis for evaluating its hydrocarbon prospectivity. In: Okogbue $\mathrm{CO}$ (ed) Hydrocarbon potentials of the Anambra Basin: geology, geochemistry and geohistory perspectives. Proceedings of the first seminar organized by the petroleum technology development fund (PTDF) chair in geology. University of Nigeria, pp 1-46

Nwajide CS (2006) A guide for geological field trips to Anambra and related sedimentary basins in South-Eastern Nigeria. Great AP Express Publishers Ltd., Nsukka

Nwajide CS (2013) Geology of Nigeria's sedimentary basins. CSS Bookshops Limited, Lagos, p 565

Nwajide CS, Reijers TJA (1996) Geology of the southern Anambra Basin. In: Reijers TJA (ed) Selected chapters on geology. SPDC, Warri, pp 133-148

Obaje NG, Ulu OK, Petters SW (1999) Biostratigraphic and geochemical controls of the hydrocarbon prospects in the Benue trough and Anambra basin, Nigeria. Niger Assoc Pet Explor Bull 14:18-54

Obaje NG, Wehner H, Scheeder G, Abubakar MB, Jauro A (2004) Hydrocarbon prospectivity of Nigeria's inland basins: from the viewpoint of organic geochemistry and organic petrology. Am Assoc Pet Geol Bull 88:325-353

Obi CG, Okogbue CO (2004) Sedimentary response to tectonism in the Campanian-Maastrichtian succession, Anambra Basin, Southeastern Nigeria. J Afr Earth Sci 38:99-108

Odumodu CFR (2014) Ichnology and lithofacies analysis of the Campano-Maastrichtian Mamu Formation in the northern parts of the Anambra Basin, Nigeria. Int J Geol Earth Environ Sci 4(3): 130-137

Odunze SO, Obi GC (2013) Sedimentology and sequence stratigraphy of the Nkporo Group (Campanian-Maastrichtian), Anambra Basin, Nigeria. J Palaeogeogr 2(2):192-208

Ojo OJ, Ajibola UK, Akande SO (2009) Depositional environments, organic richness and petroleum generating potential of the
Campanian to Maastrichtian, Enugu Formation, Anambra Basin, Nigeria. Pac J Sci Technol 10:614-628

Ojoh KA (1992) The southern part of the Benue Trough (Nigeria) Cretaceous stratigraphy, basin analysis, paleo-oceanography and geodynamic evolution in the equatorial domain of the South Atlantic. Niger Assoc Pet Explor Bull 7(2):131-152

Okogbue CO, Ugwoke TS (2012) Inferring hydrocarbon migration and sealing potentials of some shales of the Anambra Basin (Southeastern Nigeria) from their paragenesis and geotechnical index properties. Geotech Geol Eng 30:1249-1260

Onuoha KM (2005) A closer look at the petroleum potentials of the Anambra Basin-inputs from geophysics and geohistory. In: Okogbue CO (ed) Hydrocarbon potentials of the Anambra Basin. Proceedings of the first seminar organized by the Petroleum Technology Development Fund (PTDF) chair in geology. University of Nigeria, pp 47-78

Onuoha KM, Dim CIP (2017) Developing unconventional petroleum resources in Nigeria: an assessment of shale gas and shale oil prospects and challenges in the inland Anambra Basin. In: Onuoha KM (ed) Advances in petroleum geoscience research in Nigeria, Chapter 16, 1st edn. University of Nigeria, Nsukka, pp 313-328

Onyekuru SO, Iwuagwu CJ (2010) Depositional environments and sequence stratigraphic interpretation of the Campano-Maastrichtian Nkporo shale group and Mamu Formation exposures at Leru-Okigwe axis, Anambra Basin, Southeastern Nigeria. Aust J Basic Appl Sci 4(12):6623-6640

Onyekuru SO, Opara KD, Iwuagwu CJ, Opara AI (2015) Diagenetic study of sandstone sediments in parts of Anambra and Afikpo Basins, Southeastern Nigeria. FUTO J Ser 1(2):316-331

Petters SW (1991) Regional geology of Africa. Lecture notes in earth sciences, vol 40. Springer, Berlin, p 722

Tijani MN, Nton ME (2009) Hydraulic, textural and geochemical characteristics of the Ajali Formation, Anambra Basin, Nigeria: implication for groundwater quality. Environ Geol 56:935-951

Tuttle WLM, Brownfield EM, Charpentier RR (1999) The Niger Delta petroleum system. Chapter a: tertiary Niger Delta (AkataAgbada) petroleum system, Niger Delta Province, Nigeria, Cameroon and Equatorial Guinea, Africa. U.S. Geological Survey, Open File Report, 99-50-H

Umeji OP, Nwajide CS (2007) Age control and designation of the standard stratotype of Nsukka Formation of Anambra Basin, southeastern Nigeria. J Min Geol 43(2):147-166

UNN-IDSL Project Map (2012) Regional field mapping of the southeastern Nigeria. In: University of Nigeria, Nsukka/Integrated Data Services Limited-(A subsidiary of Nigerian National Petroleum Corporation-NNPC) joint venture research and development project 